\title{
ИСПОЛЬЗОВАНИЕ В ТЕХНОЛОГИИ МЯСНЫХ РУБЛЕНЫХ ПОЛУФАБРИКАТОВ МУКИ ПРОРОЩЕННЫХ СЕМЯН ИЗ НУТА
}

\author{
A.L. Alekseev, T.V. Alekseeva
}

\section{USING IN THE TECHNOLOGY OF MEAT CHOPPED SEMI-FINISHED PRODUCTS FROM THE FLOUR OF GERMINATED SEEDS FROM NUTT}

Алексеев А.Л. - д-р биол. наук, проф. каф. пищевых технологий Донского государственного аграрного университета, Ростовская обл., Октябрьский р-н, пос. Персиановский.

E-mail: cersei@mail.ru

Алексеева T.В. - канд. с.-х. наук, доц. каф. терапии и пропедевтики Донского государственного аграрного университета, Ростовская обл., Октябрьский р-н, пос. Персиановский.

E-mail: cersei@mail.ru

Одной из задач мясной промышленности является разработка пищевых продуктов нового поколения, имеющих комплементарный состав белков и характеризующихся близким к идеальному аминокислотным составом. B этом плане наиболее экономично использование белка растительного происхождения. Цель исследований - оптимизация химического состава мясо-растительных рубленых полусрабрикатов на основе внесения муки из пророщенных семян бобовой культуры нут. Работа выполнена на кафредре пищевых технологий ФГБОУ ВО «Донской государственный аграрный университет» (пос. Персиановский, Ростовская обл.). Объектами исследований являлись новые белковые комплексы на основе муки из семян пророщенного нута, контрольный и модельные фрарши, комбинированные мясо-растительные полусрабрикаты и готовые изделия; проводили предварительное проращивание семян нута, что обеспечило активизацию работу ферментативной системы, синтез белковых органелл и питательных веществ и способствовало приобретению особых качеств растительного сырья. С иелью определения оптимального количества вводимого ффункционального белкового продукта была проведена дегустационная оценка
Alekseev A.L. - Dr. Biol. Sci., Prof., Chair of Food Technologies, Don State Agrarian University, Rostov Region, Oktyabrsky District, S. Persianovsky.

E-mail: cersei@mail.ru

Alekseeva T.V. - Cand. Agr. Sci., Assoc. Prof., Chair of Therapy and Propaedeutics Don State Agrarian University, Rostov Region, Oktyabrsky District, S. Persianovsky.

E-mail: cersei@mail.ru

котлет из фрарша с добавлением $10 \%, 15$ и 20 \% муки нута взамен основного мясного сьрья. Дегустационньй мониторинг показал,что котлеты с уровнем замены мясного сырья до $15 \%$ растительной добавкой по органолептическим показателям не уступают контрольному образиу и соответствуют требованиям ГОСТ 9959-2015. Отмечено повышение пищевой ценности, увеличение монолитности и плотности фрарша, а также выхода готового продукта. Включение в состав рещептуры рубленых полусабрикатов белковых ингредиентов в виде муки из пророщенных зерен нута благоприятно сказывается на функциональнотехнологических качествах и стабильности фаршевых систем.

Ключевые слова: растительное сырье, мука из нута, химический состав, пищевая ценность, функциональные свойства, мясной рубленьй полуфабрикат.

One of the tasks of meat industry was to develop new generation of foodstuff having complementary protein composition and close to "ideal" amino acid composition. In this regard, the most economical was using protein of plant origin. The aim of the research was to optimize chemical composition of meat-and-vegetable chopped semi-finished prod- 
ucts based on the introduction of flour from sprouted legume seeds nutt. The work was performed at the Department of Food Technologies of FSBEI "Don State Agrarian University", Persianovsky, Rostov Region. The objects of the research were new protein complexes based on sprouted mouth seed flour, control and model mince, combined meat-and-vegetable semi-finished products and finished products; carried out a preliminary germinating of nutt seeds, which ensured activation of enzymatic system, synthesis of protein organelles and nutrients and contributed to the acquisition of special qualities of plant raw materials. In order to determine optimal amount of functional protein product introduced, tasting evaluation of mince cutlets was carried out with the addition of $10 \%, 15$ and $20 \%$ of nutty flour instead of the main meat raw material. Tasting monitoring showed that the cutlets with the level of meat raw material replacement up to $15 \%$ with vegetable additive according to organoleptic indices were not inferior to the control sample and met the requirements of State Standard 9959-2015. Increased nutritive value, enriched monolithic content and the density of mince, as well as the yield of finished product were noted. Inclusion of protein ingredients in the composition of chopped semi-finished products in the form of flour from sprouted nut grains had a favorable effect on functional and technological qualities and stability of mince systems.

Keywords: vegetable raw material, fly flour, chemical composition, nutritional value, functional properties, chopped meat semi-finished product.

Введение. Несмотря на постоянно растущий ассортимент продуктов питания, проблема качественной и здоровой пищи остается одной из самых актуальных. Качество питания ухудшается в условиях сложной социальной, экономической и экологической обстановки. Поэтому необходима разработка и внедрение в производство функциональных пищевых продуктов, употребление которых может способствовать сохранению и укреплению здоровья [1].

Сочетание животных и растительных ингредиентов позволяет взаимно дополнять их недостающими биологически активными веществами и быть основой для обеспечения специализированного и лечебно-профилактического питания. Наиболее близки к животным белкам по биологической ценности белки бобовых культур, в этой связи перспективно их использование в технологии производства мясных продуктов [2].

При изучении вопроса обогащения мясных продуктов нетрадиционными белковыми ингредиентами из растений представляют интерес семена нута и продукты его переработки. Несмотря на ценные свойства этой культуры, функционально-технологические характеристики недостаточно изучены [3].

Цель исследований. Использование в технологии мясо-растительных рубленых полуфабрикатов муки из пророщенных семян нута и оценка качественных характеристик полученного продукта.

Задачи исследований: провести оценку химического состава зерен нута и влияния процесса проращивания на их состав; разработать рецептуру опытных образцов котлет «Деревенские» с частичной заменой мясного сырья растительной добавкой; установить эфффективные дозировки внесения муки из зерен нута, обеспечивающие наилучшие органолептические свойства, и определить фризико-химические показатели готового продукта.

Объекты и методы исследований. Объектами исследований являлись новые белковые комплексы на основе муки из семян пророщенного нута, контрольный и модельные фарши, комбинированные мясо-растительные полуфабрикаты и готовые изделия. Использовали зерна нута - сорта Краснокутский 36 (Российская зерновая компания «Русская торговая организация»).

При выработке мясных рубленых полуфабрикатов использовали сырье в соответствии с требованиями ГОСТ 32951-2014 «Полуфабрикаты мясные и мясосодержащие. Общие технические условия» [4]; отбор средних проб готового продукта проводили по ГОСТ Р 51447-99 «Мясо и мясные продукты. Методы отбора проб» [5]; массовую долю влаги определяли по ГОСТ 33319-2015 «Мясо и мясные продукты. Метод определения массовой доли влаги» [6]; определение жира - по ГОСТ 23042-2015 «Мясо и мясные продукты. Методы определения жира» [7]; определение белка - по ГОСТ 250112017 «Мясо и мясные продукты. Методы определения белка» [8]; органолептические показа- 
тели в готовом изделии исследованы в соответствии с ГОСТ 9959-2015 «Продукты мясные. Общие условия проведения органолептической оценки» [9].

Результаты исследований и их обсуждение. Перспективность нута, как сырья для мясной промышленности, зависит главным образом от органолептических свойств, химического состава, биологической ценности и функционально-технологических характеристик. Химический состав зерен нута колеблется в зависимости от сорта и в среднем выглядит следующим образом (данные приводятся в сравнении с данными по сое, табл. 1).

Химический состав зерен нута в сравнении с соей, г

\begin{tabular}{|l|c|c|}
\hline \multicolumn{1}{|c|}{ Показатель } & Соя & Нут \\
\hline Белок & 36 & 28 \\
\hline Крахмал & 32 & 48 \\
\hline Жир & 16 & 5,5 \\
\hline Клетчатка & 4 & 4,2 \\
\hline Сахар & 7 & 8 \\
\hline Зола & 4,8 & 3,2 \\
\hline
\end{tabular}

Согласно методике исследований, было проведено проращивание семян нута. Проращивание активизирует работу ферментативной системы семян, обеспечивая синтез белковых органелл и питательных веществ, что способствовало приобретению особых качеств раститель- ного сырья. Процесс проращивания способствовал улучшению пищевой ценности функциональных элементов нута (табл. 2). После проращивания количество белка увеличилось на $1,5 \%$, количество жира снизилось на 0,5\%, произошло увеличение сырой клетчатки.

\section{Влияние процесса проращивания на химический состав нута}

\begin{tabular}{|l|c|c|}
\hline \multirow{2}{*}{\multicolumn{1}{|c|}{ Показатель }} & \multicolumn{2}{|c|}{ Содержание, \% к сухому веществу } \\
\cline { 2 - 3 } & нут до проращивания & нут после проращивания \\
\hline Влага и летучие вещества & 11,4 & 56,7 \\
\hline Сырой протеин & 24,4 & 35,1 \\
\hline Сырой жир & 4,4 & 3,9 \\
\hline Сырая клетчатка & 3,5 & 4,2 \\
\hline
\end{tabular}

По количеству незаменимых аминокислот бобовые культуры не уступают мясу, аминокислотный состав семян нута до проращивания и после представлен в таблице 3. Количество незаменимых аминокислот валина и лейцина увеличилось более чем на $60 \%$, триптофана - более чем на $70 \%$, лизина и гистидина более чем в два раза.
Процесс проращивания зерен бобовой культуры нут позволил улучшить ферментативную активность. Для оценки функциональнотехнологических качеств растительной добавки определяли влагоудерживающую способность (ВУС), жироудерживающую способность (ЖУС) и жироэмульгирующую способность (ЖЭС). Результаты оценки представлены в таблице 4. 
Аминокислотный профиль нута до и после проращивания

\begin{tabular}{|l|c|c|}
\hline \multirow{2}{*}{ Аминокислота } & \multicolumn{2}{c|}{ Количество незаменимых аминокислот, г на 100 г белка } \\
\cline { 2 - 3 } & до проращивания & после проращивания \\
\hline Валин & 15,2 & 24,1 \\
\hline Лейцин & 18,3 & 29,4 \\
\hline Изолейцин & 5,8 & 8,4 \\
\hline Треонин & 3,6 & 5,9 \\
\hline Лизин & 16,6 & 34,7 \\
\hline Метионин+цистин & 2,6 & 4,9 \\
\hline Фенилаланин & 4,5 & 8,6 \\
\hline Триптофан & 2,6 & 4,6 \\
\hline Аргинин & 19,1 & 33,2 \\
\hline Гистидин & 3,4 & 7,7 \\
\hline
\end{tabular}

Функционально-технологический потенциал нута

\begin{tabular}{|l|c|}
\hline \multicolumn{1}{|c|}{ Показатель } & Растительный ингредиент \\
\hline ВУС, г/г & 4,90 \\
\hline ЖУС, г/г & 4,87 \\
\hline ЖЭС, $\%$ & 57,64 \\
\hline
\end{tabular}

Результаты исследований свидетельствуют - высоком потенциале функциональнотехнологических свойств пророщенных семян нута и характеризуют данную культуру как пищевой ингредиент, способный к улучшению структурно-механических свойств фраршевых систем при производстве мясо-растительных изделий. Методом размола сухих пророщенных семян нута была выработана партия муки с выходом около 60 \%. Размол пророщенных семян нута способствует росту числа гидрофильных и гидрофобных центров, что благоприятно отражается на функционально-технологических свойствах получаемого продукта.

При выработке опытных образцов рубленых полуфабрикатов использовали рецептуру котлет «Деревенские» (категория В) согласно ГОСТ 32951-2014 «Полуфабрикаты мясные и мясосодержащие. Общие технические условия». На стадии фраршесоставления в опытные образцы вносили растительную добавку на основе гидролизированной муки из пророщенных семян нута взамен части мясного сырья в количестве от 10 до $20 \%$. Предварительно просеянную муку помещали в куттер, затем вносили воду ком- натной температуры в соотношении 1:1,5. Рецептура опытных образцов котлет «Деревенские» с растительной добавкой представлена в таблице 5.

Полученные данные свидетельствуют, что котлеты с уровнем замены до $15 \%$ растительной добавкой по органолептическим показателям не уступают контрольному образцу (табл. 6).

Они обладают рыхлой консистенцией, выраженным ароматом и мясным вкусом, за счет введения муки из нута изделия более пышные и сочные; внешне и на разрезе не отличались от контрольного образца - правильная форма, поверхность без трещин и сколов, равномерно обсыпана. При дегустации котлеты, содержащие нутовую муку в количестве от 10 до $15 \%$, были отмечены высокими баллами. Увеличение количества муки негативно отражается на сочности, а также прочности котлет при термическом воздействии. Введение $20 \%$ функционального ингредиента муки из пророщенного нута снижает пищевые достоинства образца № 3. Появилась крошливость при жарке, вкус и запах стали насыщенными, с яркой нотой бобового компонента, перебивающей мясную часть. 
Рецептура опытных образцов котлет «Деревенские» с растительной добавкой

\begin{tabular}{|l|c|c|c|c|}
\hline \multirow{2}{*}{ Сырье } & \multicolumn{4}{|c|}{ Норма расхода, кг на 100 кг } \\
\cline { 2 - 5 } & Контроль & $\begin{array}{c}\text { Уровень заме- } \\
\text { ны 10\% }\end{array}$ & $\begin{array}{c}\text { Уровень замены } \\
15 \%\end{array}$ & $\begin{array}{c}\text { Уровень заме- } \\
\text { ны 20 \% }\end{array}$ \\
\hline Мясо котлетное говяжье & 54,0 & 44,0 & 39,0 & 34,0 \\
\hline Жир-сырец говяжий & 5,0 & 5,0 & 5,0 & 5,0 \\
\hline Хлеб пшеничный & 13,0 & 13,0 & 13,0 & 13,0 \\
\hline $\begin{array}{l}\text { Мука из пророщенных бобов } \\
\text { нута }\end{array}$ & - & 4 & 6 & 8 \\
\hline Вода для гидратации & - & 6 & 9 & 12 \\
\hline Сухари панировочные & 2,0 & 2,0 & 2,0 & 2,0 \\
\hline Лук репчатый & 3,0 & 3,0 & 3,0 & 3,0 \\
\hline Соль поваренная & 1,2 & 1,2 & 1,2 & 1,2 \\
\hline Перец молотый & 0,1 & 0,1 & 0,1 & 0,1 \\
\hline Вода питьевая & 21,7 & 21,7 & 21,7 & 21,7 \\
\hline Итого & 100 & 100 & 100 & 100 \\
\hline
\end{tabular}

Органолептические показатели опытных образцов котлет массой 100 г

Таблица 6

\begin{tabular}{|l|l|l|l|}
\hline \multirow{2}{*}{ Показатель } & \multicolumn{1}{|c|}{ Контроль } & \multicolumn{3}{|c|}{$\begin{array}{c}\text { Образец } 1 \\
(10 \%)\end{array}$} & $\begin{array}{c}\text { Образец 2 } \\
(15 \%)\end{array}$ & \multicolumn{1}{|c|}{ Образец 3 (20 \%) } \\
\cline { 2 - 4 } Форма & \multicolumn{3}{|c|}{ Овально-округлая, приплюснутая с заостренными краями } \\
\hline Внешний вид & $\begin{array}{l}\text { Целиком панирована, округло-овальной фрормы, } \\
\text { ломаные края отсутствуют, цвет светло- } \\
\text { коричневый }\end{array}$ & $\begin{array}{l}\text { Местами края неровные, } \\
\text { присутствуют участки бе3 } \\
\text { панировки, цвет светло- } \\
\text { коричневый }\end{array}$ \\
\hline $\begin{array}{l}\text { Вид } \\
\text { на разрезе }\end{array}$ & $\begin{array}{l}\text { Консистенция однородная, нежная, некрошли- } \\
\text { вая, сочная, оптимально измельчен и переме- } \\
\text { шан фрарш, с видимыми вкраплениями жира, } \\
\text { цвет светло-розовый }\end{array}$ & $\begin{array}{l}\text { Консистенция однородная, } \\
\text { сухая структура, фарш хо- } \\
\text { рошо измельчен и переме- } \\
\text { шан, насыщенно-серый цвет }\end{array}$ \\
\hline Запах, вкус & $\begin{array}{l}\text { Свойственные жареному про- } \\
\text { дукту, без посторонних запахов } \\
\text { и привкусов }\end{array}$ & $\begin{array}{l}\text { Слабый запах } \\
\text { и тонкий прив- } \\
\text { кус бобовых }\end{array}$ & $\begin{array}{l}\text { Характерный запах и привкус } \\
\text { бобовых }\end{array}$ \\
\hline
\end{tabular}

Для определения физико-химических показателей готового продукта использовали образец с уровнем замены мясного сырья $15 \%$-й добавкой из нутовой муки. Химический анализ под- тверждает целесообразность использования данной добавки в технологии производства мясопродуктов функционального назначения (табл. 7).

Таблица 7

\section{Физико-химические показатели котлет}

\begin{tabular}{|l|c|c|}
\hline \multicolumn{1}{|c|}{ Показатель } & Контрольный образец & Опытный образец (15 \%) \\
\hline Массовая доля, \%: влаги & $68,6 \pm 0,4$ & $67,5 \pm 0,3$ \\
\hline белка & $10,5 \pm 0,3$ & $13,3 \pm 0,4$ \\
\hline pH & $5,62 \pm 0,02$ & $5,86 \pm 0,01$ \\
\hline Выход готового изделия, \% & 76,4 & 107,8 \\
\hline
\end{tabular}


За счет внесения муки из нута увеличился выход готовых изделий, в связи с тем, что добавка оказывает влияние на повышение устойчивости эмульсии фарша, способной связывать влагу и жиры, а также $\mathrm{pH}$, что меняет гидрофильность всей мясной системы и функционально-технологические свойства опытных об- разцов фарша. Значение аминокислотного скора незаменимых аминокислот в опытных образцах котлет, содержащих фрункциональный элемент - муку из зерен нута, выше 100, что свидетельствует о высоком уровне биологической ценности готовых изделий (табл. 8).

Биологическая ценность опытных образцов котлет

Таблица 8

\begin{tabular}{|l|c|c|}
\hline \multicolumn{1}{|c|}{ Аминокислота } & $\begin{array}{c}\text { Содержание аминокис- } \\
\text { лоты, г/100 г продукта }\end{array}$ & Скор аминокислоты \\
\hline Валин & 5,08 & 101,6 \\
\hline Лейцин & 7,78 & 111,1 \\
Изолейцин & 4,10 & 102,5 \\
Треонин & 4,20 & 105,0 \\
\hline Лизин & 7,30 & 132,7 \\
\hline Метионин+цистин & 3,20 & 91,4 \\
\hline Фенилаланин & 6,10 & 101,7 \\
\hline Триптосран & 1,30 & 130,0 \\
\hline Коэффрициент утилизации белка & & \\
\hline
\end{tabular}

Выводы. Разработана растительная белковая добавка из муки пророщенных семян нута и установлены эффрективные дозировки ее внесения в рецептуры полуфабрикатов из рубленого мясного сырья. Установлено, что проращивание способствует улучшению пищевой ценности функциональных элементов нута, количество белка увеличилось на 1,5\%, количество жира снизилось на 0,5 \%, произошло увеличение сырой клетчатки. Определен допустимый 15\%-й уровень замены мясного сырья добавкой, обеспечивающей наилучшие органолептические показатели, в том числе традиционный вкус и запах готового изделия. Таким образом, включение в состав рецептуры рубленых полуфабрикатов белковых ингредиентов в виде муки из пророщенных зерен нута благоприятно сказывается на функционально-технологических качествах, стабильности фаршевой системы и обогащает готовый продукт биологически ценными веществами.

\section{Литература}

1. Сергиенко И.В., Куцова А.Е., Куцов С.В. Инновационно-технологические решения в создании функциональных продуктов питания // Вестник ВГУИТ. - 2015. - № 2. C. 126-129.

2. Особенности структуры питания [Электронный ресурc]. - URL: https://www.naturalsciences.ru/pdf/2007/3/2.pdf.

3. Алексеев А.Л., Комарова З.Б. Функционально-технологические свойства нута и нутовой муки и пути его использования в рецептуре комбинированных мясопродуктов // Современные технологии производства продуктов питания: состояние, проблемы и перспективы развития: мат-лы междунар. науч.-практ. конф. - пос. Персиановский, 2012.

4. ГОСТ 32951-2014. Полусрабрикаты мясные и мясосодержащие. Общие технические условия. - М., 2014. 
5. ГОСТ Р 51447-99. Мясо и мясные продукты. Методы отбора проб. - М., 1999.

6. ГОСТ 33319-2015. Мясо и мясные продукты. Метод определения массовой доли влаги. - М., 2015.

7. ГОСТ 23042-2015. Мясо и мясные продукты. Методы определения жира. - М., 2015.

8. ГОСТ 25011-2017. Мясо и мясные продукты. Методы определения белка. - М., 2017.

9. ГОСТ 9959-2015. Продукты мясные. Общие условия органолептической оценки. - М., 2015.

\section{Literatura}

1. Sergienko I.V., Kucova A.E., Kucov S.V. Innovacionno-tehnologicheskie reshenija $\mathrm{V}$ sozdanii funkcional'nyh produktov pitanija // Vestnik VGUIT. - 2015. - № 2. - S. 126-129.

2. Osobennosti struktury pitanija [Jelektronny] resurs]. - URL: https://www.naturalsciences.ru/pdf/2007/3/2.pdf.
3. Alekseev A.L., Komarova Z.B. Funkcional'notehnologicheskie svojstva nuta i nutovoj muki i puti ego ispol'zovanija $v$ recepture kombinirovannyh mjasoproduktov // Sovremennye tehnologii proizvodstva produktov pitanija: sostojanie, problemy i perspektivy razvitija: mat-ly mezhdunar. nauch.-prakt. konf. - pos. Persianovskij, 2012.

4. GOST 32951-2014. Polufabrikaty mjasnye i mjasosoderzhashhie. Obshhie tehnicheskie uslovija. - M., 2014.

5. GOST R 51447-99. Mjaso i mjasnye produkty. Metody otbora prob. - M., 1999.

6. GOST 33319-2015. Mjaso i mjasnye produkty. Metod opredelenija massovoj doli vlagi. - M., 2015.

7. GOST 23042-2015. Mjaso i mjasnye produkty. Metody opredelenija zhira. - M., 2015.

8. GOST 25011-2017. Mjaso i mjasnye produkty. Metody opredelenija belka. - M., 2017.

9. GOST 9959-2015. Produkty mjasnye. Obshhie uslovija organolepticheskoj ocenki. - M., 2015. 